\title{
Analysis of the Influence of Character, Compensation and Teaching Experience on Teacher Professionalism in the Kepulauan Tanimbar Regency of Indonesia
}

\author{
Hendrikus Torimtubun, Syaiful Arifin, and Yarnest \\ University of Merdeka Malang \\ Indonesia
}

\begin{abstract}
This study aims to describe the character, compensation of teaching experience and teacher professionalism. The study also focuses to analyze the influence of compensation and teaching experience that has a dominant influence on teacher professionalism in the Kepulauan Tanimbar District. The number of samples in this study were 98 teachers. Data analysis techniques used multiple regression analysis, F-test and t-test. Based on the results of the analysis shows that the character, compensation and teaching experience simultaneously have a significant effect on teacher professionalism. The character, compensation and teaching experience partially have a significant effect on teacher professionalism. Teaching experience has a dominant influence on teacher professionalism.
\end{abstract}

Keywords: Character, Compensation, Teaching Experience, Teacher Professionalism.

\section{INTRODUCTION}

Teachers as educators who have the obligation to teach a science in formal educational institutions, are in charge of making lesson plans, carrying out the learning process, and assessing learning outcomes, as well as improving training and guidance as professionals. According to Kunandar Professionalism is a trait, condition, and quality that a person must have in terms of one's expertise and authority related to the profession [1]. Teachers who have high professionalism will increase the quality and quantity of their professionals through various methods and strategies in terms of advancing their education (Surya) [2].

Teacher professionalism is an important factor and very much needed by a teacher, so that teachers can work well in carrying out their main duties and improve the quality of better human resources. This shows that the importance of efforts to improve the quality of teacher education must be carried out continuously. Teacher certification is one way in the world of education to improve the quality and professionalism of a teacher.

Teacher professionalism is a picture of the condition of the teacher, that the teacher has the characteristics of the ability as a professional teacher according to predetermined conditions. Teacher professionalism is not only seen from the aspect of mastery of the subject matter, but also seen from the willingness and ability of the teacher to arouse students' enthusiasm to be more enthusiastic in participating in the learning process. Therefore the characteristics of the teachers are needed to be known more closely by students and students do not feel bored with the teaching style of the teacher. This makes it easier for teachers to transfer knowledge to students when the learning process takes place in the classroom. The teacher must also have a kind and gentle nature when learning, because the teacher becomes an example of students when they behave in any situation.

As an educator, the teacher is in charge of teaching and instilling attitude values to students. To carry out these duties, various abilities and personalities are needed. This is because the teacher is also considered an example by students so that he must have a good personality as a teacher. In the history of education development in Indonesia, many efforts have been made and various accompanying policies. However, recently the results achieved seem to indicate that something is missing that cannot be realized in our education. The decline in morals, ethics and the decline in the nation's achievements signals a strong element that this nation is facing increasingly complex problems. Cultural and character education is one of the solutions offered to minimize the shallow understanding of the noble values of the Indonesian nation. At least there are several things why the need for culture and character education is implemented in an educational context.

One thing that schools must pay attention to is how the compensation program is run in schools. Compensation is what teachers receive in exchange for teacher contributions in school. This compensation includes the entire package of benefits 
provided by the organization to its members and the mechanisms and procedures by which these benefits can be distributed (Sulistyani \& Rosidah) [3]. This compensation program is important for schools because it reflects the school's efforts to maintain human resources as the main component. In addition, compensation is also a meaningful aspect for teachers, because for teachers the compensation reflects a measure of the value of the work of teachers among the teachers themselves, their families and the community. If the compensation is given correctly,

Compensation consists of direct and indirect financial compensation. Direct compensation consists of payments in the form of wages, salaries, bonuses or commissions. Indirect compensation consists of all payments that are not covered by direct financial compensation which includes holidays, various kinds of insurance, services such as child care or religious care, and so on. Nonfinancial rewards such as praise, self-respect, and recognition can affect employee work motivation, productivity, and satisfaction (Rivai) [4].

Teacher professionalism affects the ability to carry out their duties and responsibilities. This is also determined by the increasing number of teacher teaching experiences, so that they know more about things related to learning in particular and education in general. This then becomes material for evaluation and improvement, because experience is the wisest teacher, the teacher can make his experience in teaching a learning process. meanwhile, this learning process will continue to be a lifelong process.

Teachers in Kepulauan Tanimbar Regency have good characters such as being responsible, polite, and virtuous. The teacher's character plays a role in increasing professionalism, because as a teacher, they must provide good examples for students such as behavior, appearance, teacher skills, and insight, can be role models for students. The development of increasingly sophisticated technology can affect how to think, behave and the character of students. The condition of compensation for teachers in the Kepulauan Tanimbar Regency is the delay in payment of teacher rights such as teacher professional allowances and excess teaching hours, so that teachers feel disappointed which results in a decrease in teacher professionalism. Meanwhile, seen from the teaching experience, most of the teachers in the Kepulauan Tanimbar District have quite a long teaching experience in terms of teaching, but not all teachers have had the opportunity to take part in training in order to improve teacher abilities so that it has an impact on teacher professionalism.

\section{LITERATURE REVIEW}

\subsection{Teacher Professionalism}

According to Surya Professionalism is the ability, nature and mental attitude that a person has in order to encourage him to become a professional teacher [2]. Meanwhile, according to Suyanto Professionalism is a mental attitude that a person has to create and improve his professional quality [5]. According to Sudarwan Danim in Zahroh, professionalism is an effort to optimize a person's ability to carry out his duties to become a professional by further improving the quality of compensation [6]. According to Kunandar Professionalism is someone who has the ability and authority in a job as seen from a person's situation, condition, nature and goals [1].

\subsection{Character}

Character according to Syah is a characteristic characteristic according to certain characteristics possessed by the teacher [7]. In addition, characteristics refer to a person's lifestyle and character and values that develop regularly so that behavior becomes more consistent and easy to notice. Therefore, every professional teacher is expected to have the character needed as a role model and guide for students.

The characteristics of teachers according to Hamalik can be viewed in terms of teacher responsibility, teacher functions and roles, school education objectives and the role of teachers in the teaching and learning process [8]. Furthermore, Hermawan defines character as referring to a person's lifestyle and values that develop regularly so that behavior becomes more consistent and easy to notice [9].

The teacher's character is a characteristic that is in accordance with certain characteristics possessed by the teacher which is very useful in learning activities and is needed as a role model for students and is a conspicuous habit of all those who are authorized and responsible for guiding and fostering students both individually and classically. at school and outside of school in the formal education pathway.

\subsection{Compensation}

Someone who works in an organization definitely needs adequate compensation, even if it can be quite competitive compared to other organizations or companies. A good compensation system will greatly affect one's performance. Hasibuan states that compensation is all income in the form of money, direct or indirect goods received by employees in return for services provided to the company [10]. Furthermore, Handoko argues that compensation is everything that an employee receives in return for employee work [11]. Compensation programs are also important for companies, because they reflect the organization's efforts in maintaining human resources. Wibowo argues that compensation is the number of packages that the organization offers to employees in return for using its labor [12]. Compensation according to Nawawi is an award or reward for employees who have 
contributed to realizing their goals, through activities called work [13]. Marwansyah argues that compensation is an award or reward, direct or indirect, financial or non-financial, which is fair and appropriate to employees, as a reward or contribution or service to the achievement of company goals [14].

\subsection{Teaching experience}

Muslich argues that teaching experience is "the work period of teachers in carrying out their duties as educators in certain educational units in accordance with a letter of assignment from an authorized institution" [15]. Physical evidence of teaching experience can be in the form of a legal decree or certificate from an authorized institution. Teaching experience is an experience that an individual has at the previous school. Samsudin states that "a person's ability factor is not sufficient only in terms of one's work experience while working for a particular organization or institution" [16]. Furthermore, Suyitno states that "the teaching experience is the length of time the teacher teaches a lesson. A teacher with a lot of experience in teaching will find it easier to carry out higher quality teaching and learning activities [17].

\subsection{Hypothesis}

Based on the theoretical foundation and conceptual framework that has been described, the following research hypotheses can be formulated:

1) It is suspected that character, compensation and teaching experience simultaneously have a significant effect on teacher professionalism in the Kepulauan Tanimbar Regency.

2) It is assumed that character, compensation and teaching experience partially have a significant effect on teacher professionalism in the Kepulauan Tanimbar Regency.

3) It is suspected that teaching experience has a dominant influence on teacher professionalism in the Kepulauan Tanimbar Regency.

\section{RESEARCH METHODS}

\subsection{Operational Definition of Research Variables}

a. Character

Character is a characteristic inherent in a teacher. Character indicators used in this study are as follows: teacher cognitive flexibility and teacher personal psychological openness

b. Compensation

Compensation is teacher mastery based on job characteristics. Compensation is measured by the following indicators: Pedagogic compensation, Personality compensation, Professional compensation and social compensation

c. Teaching experience

Teaching experience is the teacher's tenure in carrying out educational tasks so as to facilitate teaching and learning activities. The indicators used are as follows: following education and training and years of service.

d. Teacher professionalism

Performance is the mastery of the material and the teacher's ability to manage the class. The indicators used are: competence, effectiveness, efficiency, responsibility

\subsection{Population and Sample}

Population is the totality of all possible values, both counting results and quantitative and qualitative measurements rather than certain characteristics regarding a complete and clear group of objects (Sudjana) [18]. Another definition states that a population is a group of objects, whether humans, symptoms, test scores, objects or events (Arikunto) [19]. The population in this study were all teachers in the Kepulauan Tanimbar Regency, amounting to 4,647 teachers. The sample is the smallest part of the population that still has the characteristics and characteristics of the population to be subject to research. Taking the sample size in this study using the Slovin formula, in order to obtain a total sample of 98 teachers. The sampling technique used simple random sampling:

\subsection{Data analysis technique}

The data analysis technique used is multiple regression analysis. Multiple Linear Regression Analysis is used to determine the effect of character, compensation and teaching experience on teacher professionalism in the Kepulauan Tanimbar District, multiple linear regression is used with the help of the SPSS program with the equation:

$\mathrm{Y}=\mathrm{a}+\mathrm{b} 1 \mathrm{X} 1+\mathrm{b} 2 \mathrm{X} 2+\mathrm{b} 3 \mathrm{X} 3+\mathrm{e}$

Information :

$\mathrm{Y} \quad=$ Teacher professionalism

$\mathrm{a}=$ constant numbers 
b1..b3 $=$ regression coefficient

$\mathrm{X} 1=$ character

$\mathrm{X} 2=$ compensation

$\mathrm{X} 3=$ teaching experience

$\mathrm{e}=$ confounding variable

\section{RESULTS AND DISCUSSION}

\subsection{Multiple Regression Analysis}

From the results of data processing using the SPSS assistance program, the analysis results are obtained as in the following table:

Table1 Recapitulation of the Results of Multiple Linear Regression Analysis

\begin{tabular}{|c|c|c|c|c|}
\hline Variable & Regression Coefficient & t value & Sig. & Information \\
\hline Characters (X1) & 0.284 & 5,430 & 0,000 & Significant \\
\hline Compensation (X2) & 0.204 & 3,981 & 0,000 & Significant \\
\hline Teaching experience (X3) & 0.298 & 5,892 & 0,000 & Significant \\
\hline Constant & 0.900 & & & \\
\hline $\mathrm{R}$ & 0.864 & & & \\
\hline Adjusted R square & 0.739 & & & \\
\hline Fcount & 92.376 & & & \\
\hline Sig. F & 0,000 & & & \\
\hline $\mathrm{n}$ & 98 & & & \\
\hline \multicolumn{5}{|c|}{ The dependent variable $=$ teacher professionalism $(\mathrm{Y})$} \\
\hline $\begin{array}{l}\mathrm{F} \text { table }=2.84 \\
\mathrm{t} \text { table }=2,000\end{array}$ & & & & \\
\hline
\end{tabular}

Based on the recapitulation table, the following multiple regression equation is obtained:

$\mathrm{Y}=0.900+0.284 \mathrm{X} 1+0.204 \mathrm{X} 2+0.298 \mathrm{X} 3$

Based on this equation, it can be explained as follows:

$\alpha=0.900$ is a constant which means that if all the variables are independent, Character $\left(\mathrm{X}_{1}\right)$, compensation $(\mathrm{X} 2)$, and teaching experience (X3) is 0 , then the magnitude of the teacher professionalism variable is 0.900 .

$\beta 1=0.284$ is the regression coefficient of the independent variable Character $\left(X_{1}\right)$, the regression coefficient is positive, indicating that the character has a unidirectional effect on teacher professionalism, meaning that the better the character, the higher the teacher's professionalism, assuming that the compensation variable (X2) and teaching experience (X3) are fixed. While the influence of character on teacher professionalism is 0.284

$\beta 2=0.204$ is the magnitude of the regression coefficient for the independent variable compensation $\left(\mathrm{X}_{2}\right)$, the regression coefficient is positive, indicating that compensation has a unidirectional effect on teacher professionalism, meaning that the better the application of compensation, it causes teacher professionalism to increase with the assumption that the character variable (X1) and teaching experience (X3) are fixed. While the effect of compensation on teacher professionalism is 0.204 .

$\beta 3=0.298$ is the magnitude of the regression coefficient of the teaching experience independent variable $\left(\mathrm{X}_{3}\right)$, the regression coefficient is positive, indicating that teaching experience has a unidirectional effect on teacher professionalism, meaning that the higher the teaching experience, the teacher professionalism has increased, assuming the variable Character (X1), and compensation (X2) is fixed. While the effect of teaching experience on teacher professionalism is 0.298.

The multiple correlation coefficient $(\mathrm{R})$ of 0.864 indicates a very strong relationship between character (X1), compensation (X2) and teaching experience (X3) along with teacher professionalism (Y). Determined coefficient value (Adjusted R square) of 0.739. This coefficient of determination means that character (X1), compensation (X2) and chronic satisfaction (X3) together can contribute to teacher professionalism by $73.9 \%$, while the remaining $26.1 \%$ is caused by other variables not included in the study.

\subsection{Hypothesis test}

a. First Hypothesis Test

To test the first hypothesis which states that character, compensation and teaching experience simultaneously have a significant effect on teacher professionalism Kepulauan Tanimbar Regency, using the F test. Based on the results of the calculation of the F test with SPSS obtained Fcount of 92.376, while the F-table in $\alpha=5 \%$, df1 = 3, and df $2=94$ at 2.70 ; this means that Fcount $>$ Ftable (92.376)> 2.70) while the probability value is smaller than $\alpha=0.05(0.000<0.05)$, then Ho is 
rejected and $\mathrm{Ha}$ is accepted which means that the independent variables: character, compensation, and teaching experience simultaneously have a significant effect on teacher professionalism. Thus the first hypothesis is statistically tested.

b. Second Hypothesis Test

To test the second hypothesis which states Character, compensation and teaching experience partially have a significant effect on teacher professionalism Kepulauan Tanimbar Regency, using the $t$ test. Based on the $t$ test results obtained as follows:

1) The results of the $t$ test for the character variable obtained tcount $=5.430$ while the value of ttable $=2,000$ so that tcount $>$ ttable or a significance value of $0.000<0.05$ so Ho was rejected or Ha was accepted, and it was proven that the character variable (X1) had a significant effect on teacher professionalism (Y).

2) The results of the t-test for the compensation variable obtained tcount $=3.981$ while the value of ttable $=2,000$ so that tcount $>$ ttable or a significance value of $0.000<0.05$ so Ho was rejected or Ha was accepted, and it was proven that the compensation variable (X1) had a significant effect on teacher professionalism (Y).

3) The results of the $t$ test for the teaching experience variable obtained the value of $t=5.892$ while the value of $t$ table $=$ 2,000 so that tcount $>$ ttable or a significance value of $0.000<0.05$ so Ho was rejected or Ha was accepted, and it was proven that the teaching experience variable (X1) had a significant effect on teacher professionalism (Y ).

Based on the results of the $t$ test, it shows that character, compensation and teaching experience partially affect teacher professionalism. Thus the second hypothesis is statistically tested.

c. Third Hypothesis Testing

To test the third hypothesis which states that teaching experience has a dominant influence on teacher professionalism in Kepulauan Tanimbar Regency,by using the $t$ test and seeing the magnitude of the regression coefficient of each variable. Based on the results of the $t$ test, it is evident that character, compensation and teaching experience partially have a significant effect on teacher professionalism. Meanwhile, to find out which variables have a dominant influence on teacher professionalism, by looking at the size of the regression coefficient that affects teacher professionalism. The independent variable that has the largest and significant coefficient is the variable that has a dominant influence on teacher professionalism. Based on the results of multiple regression analysis, it can be seen that the largest regression coefficient value, namely the teaching experience of 0.410 , means that the teaching experience has a dominant influence on teacher professionalism.

\subsection{Discussion of Research Results}

\subsubsection{Character Description, Compensation, Teaching Experience and Teacher Professionalism}

Character is determined by the teacher's cognitive flexibilityand teachers' personal psychological openness. The main contribution to the character is teacher cognitive flexibility reflected by The teacher is on time when the lesson starts. Teachers as teacher educators must act guiding in the sense of guiding according to good principles and directing the development of students in accordance with the aspired goals, including in this case the most important part in solving problems and difficulties faced by students. Thus it is expected to create better development in students, both physical and mental development. Teachers are the spearhead of the back and forth of the world of education, because teachers are directly involved in the world of education practically in the field. Especially with regard to learning as well as interacting with the learning progress of students in delivering subject matter, to achieve learning objectives,

Compensation is formed by direct financial compensation and indirect compensation. The main thing that can shape compensation is the direct financial compensation reflected fromthe amount of salary received is in accordance with expectations. Providing compensation to teachers is not only a form of appreciation to teachers for results but also has several objectives. In order for this goal to be achieved and to provide satisfaction to all parties, compensation should be determined based on fair and reasonable principles and applicable laws. Compensation can be in the form of direct financial compensation or indirect compensation. Compensation given to teachers can motivate teachers or even discourage teachers from working, therefore the policy regarding compensation is one of the important policies that schools must pay attention to, especially in order to improve work performance. With the principle of fairness, an atmosphere of good cooperation will be created, morale, discipline, loyalty and teacher stability will be better.

Teaching experience is shaped by attending training courses and years of service. The main thing that can create a teaching experience is taking part in training education, which is reflected in every teacher getting the opportunity to be included in education and training. Teaching experience is what has been experienced in teaching in schools with regard to time. Teaching experience is one of the factors that can support the implementation of teaching and learning activities. The teaching experience possessed by a teacher determines the achievement of learning outcomes that will be achieved by students. Sufficient teaching experience, in the sense that the time passed by a teacher in carrying out his duties, will support the achievement of maximum student achievement as a goal to be achieved by the school. Teaching experience is a matter of concern that is no less important in determining student achievement. Teachers who have adequate teaching experience will positively support students to more easily 
understand the material taught by the teacher. Conversely, if the teaching experience possessed by the teacher is inadequate, it will not support the success of students in achieving the desired achievements.

Teacher professionalism is shaped by competence, effectiveness, efficiency and responsibility. The main thing that can shape teacher professionalism is the competence reflected in the respondent's broad knowledge. Teachers can be said to be professional teachers if the teacher is able to produce students who have extensive knowledge and are able to master the lessons given as well as possible. Professional teachers are required to be able to make a new breakthrough about the learning system. About how to make an effective learning methodology to be applied to their students. Unique and interesting learning methods will greatly assist students in understanding the lessons given. Professional teachers must be able to be inspiring, creative, and innovative teachers.

\subsubsection{The Influence of Character, Compensation and Simultaneous Teaching Experience on Teacher Professionalism}

Character, compensation and teaching experience simultaneously affect teacher professionalism. This shows that teachers who have good character, and are supported by the provision of fair compensation, and adequate teaching experience can improve teacher professionalism. Teacher professionalism in teaching is only owned by teachers who have broad insight and are able to explore material in language that is easily understood by students, always keep up with developments in technology and information, and teachers are also able to utilize technology and information to support learning. As an opinion Danim in Zahroh, which states that professionalism is an attempt to optimize a person's ability to carry out his duties to become a professional by further increasing the quality of compensation [6].

The teacher as an educator is a determining factor for successesan every educational endeavor. Professional teachers are people who have special abilities and expertise in the field of teacher training so that teachers are able to carry out their duties and functions as teachers with maximum abilities and always master the material or subject matter that will be taught in teaching and learning interactions, and always develop their abilities sustainably, both in in terms of knowledge and experience.

\subsubsection{The Influence of Character, Compensation and Partial Teaching Experience on Teacher Professionalism}

Teacher character has a significant effect on teacher professionalism, which means that the better the teacher's character in terms of teacher cognitive flexibility and teacher personal psychology can increase teacher professionalism. The teacher character indicator that makes the biggest contribution to the improvement of teacher professionalism is the teacher's cognitive flexibility, which is reflected in the timing of the lesson. Therefore, the characteristics of a professional teacher must master the curriculum, be skilled in using learning methods, speak the material of all subjects, have a high commitment to their duties, have discipline in the broadest sense, have a good personality, have a healthy physique, master scientific knowledge. or broad knowledge and have good skills. As the opinion of Syah which states that character is a distinctive character in accordance with certain characteristics possessed by the teacher [7]. In addition, characteristics refer to a person's lifestyle and character and values that develop regularly so that behavior becomes more consistent and easy to notice. The results of this study are supportive Ni'mah which states that character affects teacher professionalism [20].

Compensation has a significant effect on teacher professionalism, which means that the better compensation for teachers can increase teacher professionalism. The compensation indicator that provides the largest contribution to improving teacher professionalism is direct financial compensation as reflected in the amount of salary received as expected. Providing compensation is one way to foster enthusiasm at work. Teachers who have a passion for teaching can easily improve their performance at work, providing compensation to teachers can also improve teacher welfare and have an impact on teacher professionalism. The compensation given must be proportional to what the educator provides because the school must be able to be fair to all educators. so that educators can provide good performance for schools. As the opinion of Hasibuan states that compensation is all income in the form of money, direct or indirect goods received by employees in return for services provided to the company [10]. Providing fair and correct compensation can motivate teachers to complete work on time. Compensation that is adequate and in accordance with teacher expectations, teachers can be motivated to make the best contribution to school. Conversely, if the teacher feels dissatisfied with the compensation he receives, the teacher will feel lazy in carrying out his work, this certainly affects teacher professionalism. The results of this study support Ulfah et al., Abdillah and Ismiyati, and Rahmawati et al. which states that compensation has an effect on teacher professionalism [21, 22, 23].

Teaching experience has a significant effect on teacher professionalism, which means that the more experienced teachers are in teaching, it can increase teacher professionalism. The teaching experience indicator that makes the biggest contribution to improving teacher professionalism is taking part in training education, which is reflected in every teacher getting the opportunity to be included in education and training. Experienced teachers will find it easier to deal with students 'problems in the teaching and learning process related to the subject matter, even teachers are able to motivate and encourage students' enthusiasm for learning and are able to optimize the ability of teachers. Teachers who have a longer tenure will have more experience in learning than teachers who are relatively new.authorized. Teachers who have experience using learning resources in a planned and programmed manner tend to have the ability to manage learning well. The research results are supportive Firdaus, Abdillah and Ismiyati, and Rahmawati et al prove that teaching experience affects teacher professionalism [24, 22, 23]. 


\subsubsection{The Effect of Teaching Experience on Teacher Professionalism}

Teaching experience has a dominant influence on teacher professionalism, which means that the main thing that can improve teacher professionalism. Teaching experience is the teacher's working period in carrying out duties as an educator in matters experienced in teaching and is related to teacher competency values which are expected with the more experience the teacher teaches, the teacher competence in teaching is also good.

When teachers enter the world of work, they will be faced with various circumstances, both those that support or hinder the teaching and learning process. The various kinds of situations faced by the teacher will certainly encourage the teacher to find a solution. The longer the teacher teaches, the more useful the teacher should get. Beneficial experience to be acquiredAtkan the teacher can be used to correct and improve the teaching and learning process he does. Professional teachers should continue to seek valuable experiences to support their success in becoming professional teachers. Sumitro says, what teachers need to pay attention to is that they must constantly improve their experience, so that they have a lot of experience and quality that can support success in carrying out their duties and obligations [25]. Experience is a good teacher, because the skills to solve problems in the teaching and learning process are less obtained by the teacher through the formal education that the teacher takes, but is more based on the experience that the teacher has gained during the teacher's teaching. The useful experiences gained during teaching will be able to affect the quality of teachers in teaching and teacher professionalism. Professional teachers are a determining factor for the quality education process. In order to become a professional teacher, teachers must be able to find their identity and actualize themselves according to the abilities and principles of a professional teacher. The research results are supportive Firdaus, Abdillah and Ismiyati, and Rahmawati et al prove that teaching experience affects teacher professionalism [24, 22, 23].

\subsection{Implications of Research Results}

Teacher professionalism is influenced by character, compensation and work experience. Professional teachers are a determining factor for the quality education process. In order to become a professional teacher, the teacher must be able to discover the character of the teacher and actualize himself. Hermawan states that character refers to a person's lifestyle and values that develop regularly so that behavior becomes more consistent and easy to notice [9]. A teacher is said to be a professional teacher if the teacher is able to produce quality students who have broad knowledge and are able to master the lessons given as well as possible. Professional teachers are required to be able to make a new breakthrough regarding the learning system.

High professionalism is only owned by teachers who have broad insight. The teacher must master the material in depth, so as to be able to explore the material in language that is easily understood by students. Professional teachers, always following the development of technology and information, and are able to take advantage of technology and information to support learning. As is the view Surya which states that professionalism is the ability, nature and mental attitude that a person has in order to encourage him to become a professional teacher [2].

Teacher professionalism in teaching is the teacher's ability to create an effective teaching and learning process. One way of management to improve teacher professionalism is to motivate teachers by providing compensation, both financial compensation and non-financial compensation. Compensation is often an award given to teachers in return for contributions that teachers make to schools. As opinion Handoko states that compensation is anything that an employee receives in return for employee work [11].

Teacher professionalism is also influenced by teacher work experience. Work experience is the level of mastery of knowledge and skills that teachers have at work which can be measured from the length of service and the type of work the teacher has done during a certain period. Experienced teachers will have steady and fluid movements, rhythmic movements, respond more quickly to signs, be able to predict difficulties so they are better prepared to face them, and work calmly. Teachers who have a longer work experience will be more professional in learning than teachers who have little work experience. This is in accordance with the opinion of Suyitno (2012) which states that "teaching experience is the length of time the teacher teaches lessons.

\section{CONCLUSIONS AND RECOMMENDATIONS}

\subsection{Conclusion}

1) The descriptive statistical results show that character is determined by the teacher's cognitive flexibility and the teacher's personal psychological openness. The main contribution to character is the cognitive flexibility of the teacher as reflected in the teacher on time when starting lessons. Compensation is formed by direct financial compensation and indirect compensation. The main thing that can form compensation is direct financial compensation, which is reflected in the amount of salary received as expected. Teaching experience is shaped by attending training courses and years of service. The main thing that can create a teaching experience is taking part in training education, which is reflected in every teacher getting the opportunity to be included in education and training. Teacher professionalism is shaped by competence, effectiveness, efficiency and responsibility.

2) Character, compensation and teaching experience simultaneously have a significant effect on teacher professionalism, which means that to improve teacher professionalism it is necessary to have good character, compensation in accordance with teacher expectations and experience in teaching. 
3) Character, compensation and teaching experience partially have a significant effect on teacher professionalism, which means that the better the character of the teacher can increase teacher professionalism. Providing compensation in accordance with teacher expectations can increase teacher professionalism. Teachers who have more experience in teaching can increase teacher professionalism.

4) Teaching experience has a dominant influence on teacher professionalism, this shows that the main thing that can improve teacher professionalism is teaching experience.

\subsection{Suggestion}

1) In order to improve the character of teachers for the better, the teachers should be more patient in providing learning to students.

2) The school provides health insurance and holiday allowances on time so that teachers are more enthusiastic in the teaching and learning process.

3) The teachers further enhance their teaching experience so that teachers are more professional in overcoming problems in the teaching and learning process.

4) Teachers are more careful in completing work and are courageous and willing to take risks in making decisions to complete work.

5) It is suggested for further researchers to add other variables to increase teacher professionalism, such as abilities and skills.

\section{REFERENCES}

1. Kunandar. 2011. Penelitian Tindakan Kelas Sebagai pengembangan Profesi Guru. Jakarta : PT Rajagrafindo Persada

2. Surya, Mohamad. 2003. Psikologi Konseling. Bandung: Pustaka Bani Quraisy.

3. Sulistyani, Ambar T. dan Rosidah. 2013. Manajemen Sumber Daya Manusia. Cetakan. Pertama. Penerbit Graha Ilmu. Yogyakarta.

4. Rivai, Veithzal. 2009. Manajemen Sumber Daya Manusia Untuk Perusahaan. Jakarta : Raja Grafindo Persada.

5. Suyanto. 2013. Menjadi Guru Profesional. Jakarta: Erlangga

6. Zahroh, Aminatul. 2015. Membangun Kualitas Pembelajaran melalui Dimensi Profesionalisme Guru. Bandung : Yrama Widya.

7. Syah, Muhibbin Syah. 2009. Psikologi Pendidikan dengan Pendekatan Baru. Bandung: Remaja Rosdakarya.

8. Hamalik, Oemar, 2004, Proses Belajar Mengajar, Jakarta : Bumi Aksara.

9. Aksan, Hermawan. 2014. Pendidikan Budaya dan Karakter Bangsa. Bandung: Nuansa Cendekia.

10. Hasibuan, Malayu S.P.. 2017. Manajemen Sumber Daya Manusia. Edisi Revisi. Jakarta: Bumi Aksara.

11. Handoko, T. Hani. 2014. Manajemen Personalia dan Sumber Daya Manusia. BPFE, Yogyakarta.

12. Wibowo. 2016. Manajemen Kinerja. Jakarta : Raja Grafindo Persada.

14. Marwansyah. 2016. Manajemen Sumber Daya Manusia. Bandung: Alfabeta.

15. Muslich, Masnur. 2014. KTSP Pembelajaran Berbasis Kompetensi dan Konstektual. Jakarta: PT Bumi Aksara.

16. Samsudin, Salidi. 2010. Manajemen Sumber Daya Manusia. Bandung Penerbit Pustaka Setia

17. Suyitno, Amin. 2012. Dasar-dasar Proses Pembelajaran Matematika I. Semarang: Jurusan Pendidikan Matematika. F MIPA UNNES.

18. Sudjana. 2008. Metode Statistika. Edisi Revisi, Cet. 6, Bandung: Tarsito.

19. Arikunto, Suharsimi. 2009. Dasar-dasar Evaluasi Pendidikan. Jakarta:Bumi Aksara

20. Ni’mah, Fahmi Ulin. 2018. Pengaruh Karakter dan Multicultural Personality Terhadap Profesionalisme Guru Abad 21 Melalui Pengembangan Keprofesian Berkelanjutan (PKB)(Penelitian Pada Guru SMK Bisnis dan Manajemen di Kota Surakarta). Disertasi. UNS (Sebelas Maret University).

21. Ulfah, Choiriyah, Yovitha Yuliejantiningsih, dan A. Y. Soegeng. 2016. Pengaruh Kompensasi Dan Motivasi Kerja Terhadap Profesionalisme Guru Paud di Kecamatan Ungaran Barat Kabupaten Semarang. Jurnal Manajemen Pendidikan (JMP). Vol 5. No. 2: 229-241.

22. Abdillah, Zuhdan Kamal, and Ismiyati Ismiyati. "Pengaruh pengalaman mengajar, iklim kerja dan kompensasi terhadap kompetensi profesional guru di SMK Kristen Salatiga." Economic Education Analysis Journal 6.1 (2017): $255-267$.

23. Rahmawati, Sri. 2015. Pengaruh Pelatihan, Pengalaman Mengajar dan Kompensasi Terhadap Profesionalisme Guru di SMK Negeri 3 Palu. Katalogis. Volume 3 No. 12: 67-75.

24. Firdaus, Daniatul. 2014. Pengaruh Tingkat Pendidikan, Pelatihan, Dan Pengalaman Mengajar Terhadap Profesionalitas Guru Di Madrasah Tsanawiyah Negeri Kediri. Didaktika Religia. Vol. 2 No. 2: 159-182.

25. Sumitro. 2001. Ekonomi Pembangunan. Pustaka. Ekonomi: Jakarta. 